\title{
The Center Page
}

\section{Centennial Scholar Profiles}

\section{CAROLINA FERREROSA YOUNG}

Carolina Ferrerosa Young is a $\mathrm{PhD}$ candidate in political science at Columbia University, currently serving as a visiting scholar at the APSA Centennial Center for Political Science and Public Affairs in Washington, DC. She studies congressional responsiveness to interest group advocacy. Using both observational and experimental methods, she analyzes the circumstances under which members of

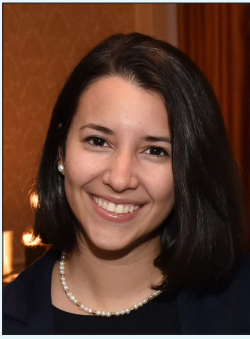
the US Congress respond to advocacy organizations, focusing primarily on those that represent marginalized communities. Her research is supported by the APSA Minority Fellowship program and the National Science Foundation Graduate Research Fellowship.
Ferrerosa Young knows firsthand how difficult it can sometimes be for researchers to understand the inner workings of institutions from the outside looking in. The visiting scholar position at the Centennial Center has allowed her to partner with a Washington-based Latino political advocacy organization that has generously invited her to observe their lobbying days on Capitol Hill. She has been able to observe lobbying strategies up close during closed meetings with members of Congress and their staff-a helpful opportunity to witness persuasion tactics and legislators' responses.

This coming fall, Carolina will get a chance to see Congress from a different perspective: she will serve as a 2017-2018 APSA Congressional Fellow. She believes serving in Congress this coming year will provide invaluable insights and make her a more incisive scholar as well as an effective educator in the years to come.

\section{VIRGINIA BEARD}

Virginia Beard is a visiting scholar with the Centennial Center while leading a group of 22 college students from her home institution who are interning at various sites around Washington, DC. Her scholarship as part of the Centennial Center involves two projects that are part of her ongoing research agenda. The first project is an extension of over a decade of work that began with her dissertation, assessing foundations for democratic growth and consolidation in emerging African democracies. Her current investigation in this vein is investigating the persistence and perpetuation of politicized ethnicity as a divisive factor undermining democracy and stability. Using Afrobarometer data to describe ethnic perspectives as well as content analysis of major print media venues in Kenya, Beard is analyzing the extent and forms that ethnic politics take both during and apart from electoral cycles.

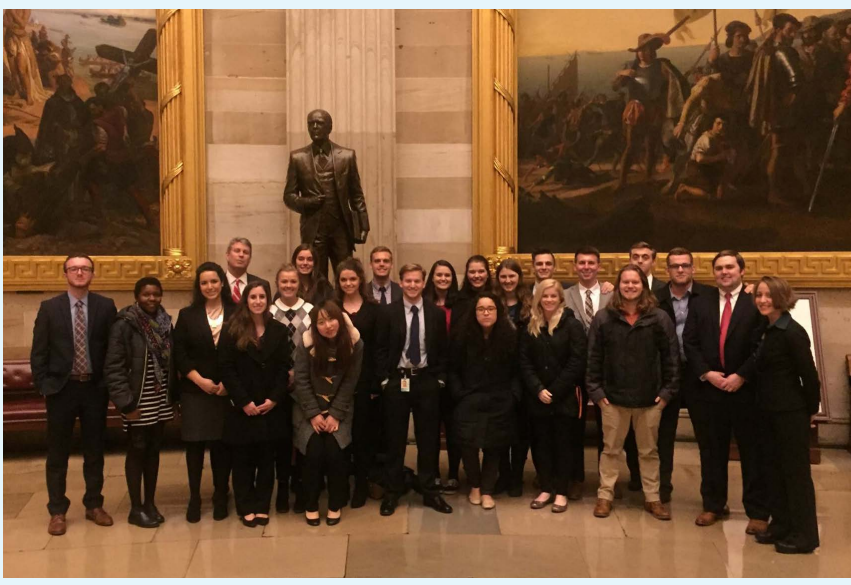

Hope College Washington, DC Honors program students gather in the Rotunda of the US Capitol during an evening tour with their representative from Michigan's second district, Bill Huizenga (fourth from left) and Virginia Beard (right).
Beard's second project focuses on the domestic context, evaluating framing of and resulting policy seeking to curtail homelessness. Beard is working toward a book project on the political history of homelessness with the goal of creating better understanding of why homelessness exists in the forms it currently does and why people who experience homelessness are viewed and treated as they are. Thus she is using historical event analysis of a uniquely created data set beginning with the first federal involvement in housing issues-a federal census of former slave dwellings conducted in 1887-through the most recent reauthorizations of the McKinney-Vento/HEARTH Act to understand the explanations and responses-individual versus structural-to homelessness at the federal level. She is also working with an economist colleague to investigate possible market-based solutions to homelessness.

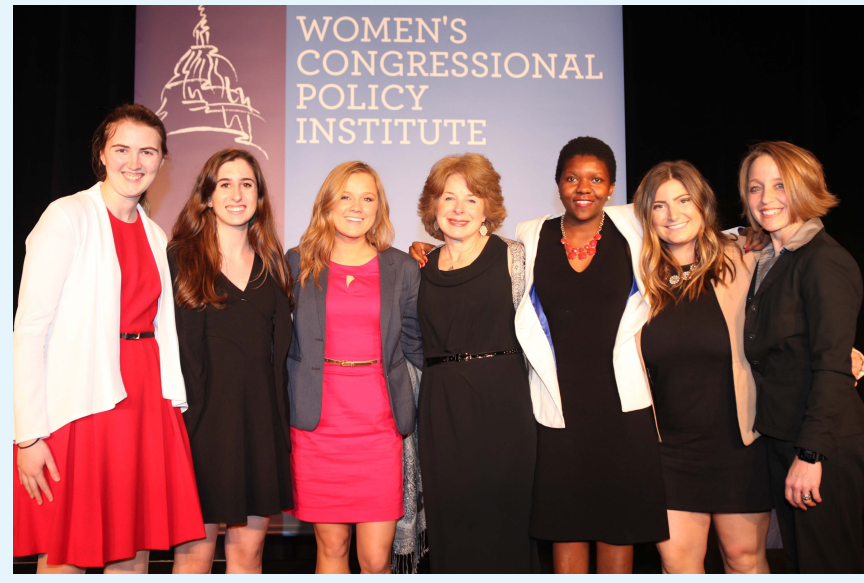

Hope College Washington, DC Honors students stop for a picture with Virginia Beard (right), and Hope alumna Amy Plaster (center), Director of the Board for the Women's Congressional Policy Institute at their annual gala, March 1, 2017. 